\title{
Primary anatomic reconstruction in upper and lower lips: case report
}

Reconstrução anatômica primária em lábios superiores e inferiores: relato de caso Reconstrucción anatómica primaria en labio superior e inferior: reporte de caso

Henrique HADAD, DDS

Laís Kawamata de JESUS, DDS

Ana Flávia Piquera SANTOS, DDS

Rodrigo CAPALBO-SILVA, DDS

Bruno Coelho MENDES, DDS

Breno Fernandes dos REIS, DDS

Gabriel MULINARI-SANTOS, DDS, MSC

Francisley Ávila de SOUZA, DDS, MSc, PhD

São Paulo State University (UNESP), School of Dentistry, Araçatuba 16015-050 Araçatuba-SP, Brazil

\section{Abstract}

Extensive lip injuries reconstructions require a strategy of treatment. First, the strategy can follow the anatomical references in order to closure the injury reestablishing the lip functions. This article report a reconstruction of an extensive lip injury after a convulsion and a fall in height in a male patient. The lip reconstruction by anatomical reconstruction was effective for immediate structural maintenance and allowed a favorable healing for the second surgical stage.

Descriptors: Lip; Wounds and Injuries; Surgery, Oral.

\section{Resumo}

Reconstruções extensas de lesões labiais requerem uma estratégia de tratamento. Primeiro, a estratégia pode seguir as referências anatômicas, a fim de fechar a lesão restabelecendo as funções labiais. Este artigo relata uma reconstrução de uma lesão extensa de lábio após uma convulsão e uma queda de altura em um paciente do sexo masculino. A reconstrução labial por reconstrução anatômica foi eficaz para manutenção estrutural imediata e permitiu uma cicatrização favorável para o segundo estágio cirúrgico.

Descritores: Lábio; Ferimentos e Lesões; Cirurgia Bucal.

\section{Resumen}

La reconstrucción extensa de los labios requiere una estrategia de tratamiento. Primero, la estrategia puede seguir referencias anatómicas para cerrar la lesión restaurando la función del labio. Este artículo informa sobre la reconstrucción de una lesión labial extensa luego de una convulsión y una caída de altura en un paciente masculino. La reconstrucción del labio mediante reconstrucción anatómica fue efectiva para el mantenimiento estructural inmediato y permitió una curación favorable para la segunda etapa quirúrgica.

Descriptores: Labio; Heridas y Traumatismos; Cirugía Bucal.

\section{INTRODUCTION}

The lips play an important dynamic for aesthetics and functional aspects, as well as communication, sound production, facial expressions, swallowing and preservation of lip sealing ${ }^{1,2}$. Extensive lip injures are a challenge for surgical reconstruction due to the need to reestablish the lip competence and many approaches or procedures can be performed ${ }^{3}$. And even minor lip defects require meticulous reconstruction to minimize injury defects because the lips are within the field of observation of the face ${ }^{4}$. Some lip injuries cause significant aesthetic and functional impairment, especially when affecting the skin, lip vermilion mucus, orbicularis muscle and oral mucosa can compromise speech, feeding, mimicry, and expression ${ }^{5}$.

Strategies for reconstruction of these injuries should aim at restoring anatomical and oral functions, as well as the satisfactory restoration of aesthetics, being fundamental for a better quality of life $\mathrm{e}^{4,6-8}$. In lips reconstructions, tissue loss and postoperative limitations should be considered ${ }^{7,8}$. This article describes a case of lip laceration upper and lower limb caused by falling of its own height.

\section{CLINICAL CASE}

A 59-year-old male patient was referred at the Hospital (Santa Casa de Misericórdia de Araçatuba, SP, Brasil) with a history of convulsion and a fall in height, resulting in extensive laceration of the upper and lower lips (Figure 1). The lip injury of total thickness, involvement of the buccal commissure, partial avulsion of the vermilion of the upper lip and laceration of the lower lip on the right side (Figure 2).

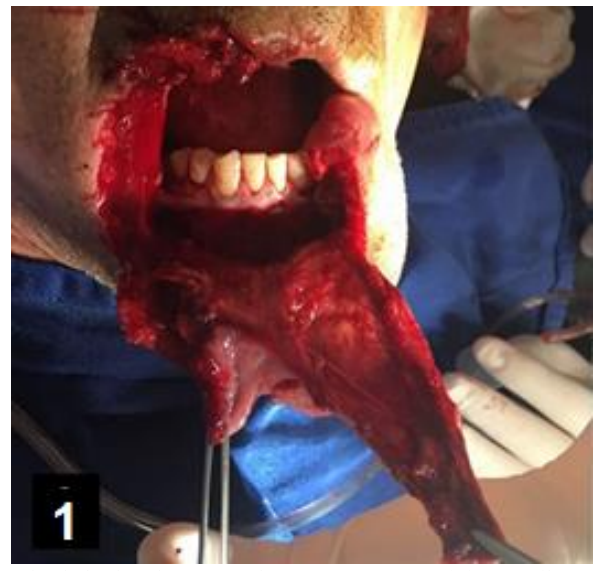

Figure 1: Lip injuries in commissure, upper and lower lip on the right side. Appearance after lip hemostasis.

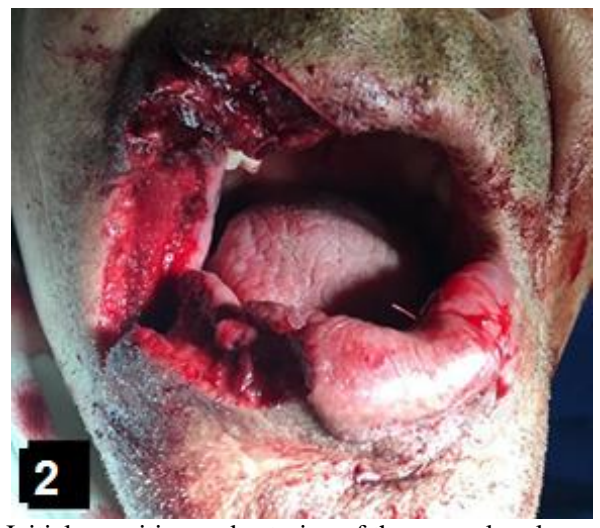

Figure 2: Initial reposition and suturing of the muscular plane. 
After the initial treatment, without further alterations, the lip injury was cleaned and direct closure in the anatomical references (Figure 3). The aesthetic result presented after 30 days revealed a cicatricial contracture, mucocutaneous misalignment and lack of lip vermilion in the region of the right buccal commissure and lip incompetence (Figure 4). The labial functions as speech, mimicry, feeding remained with some limitations. In view of the above, the patient will undergo secondary surgery to correct the resulting deficiencies.

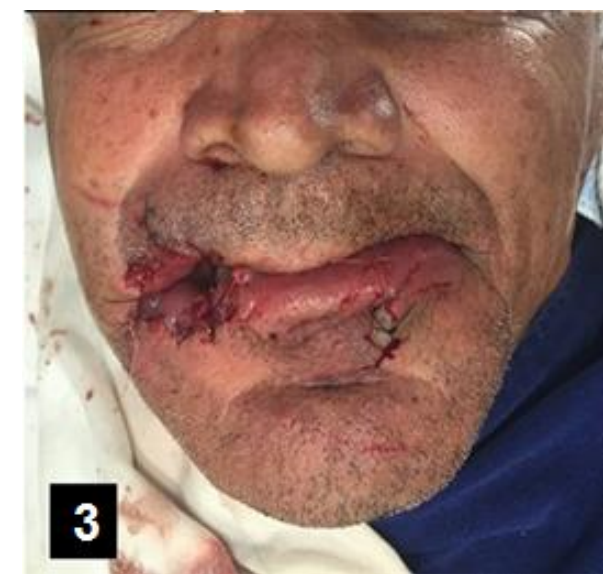

Figure 3: Immediate appearance after lip reconstruction

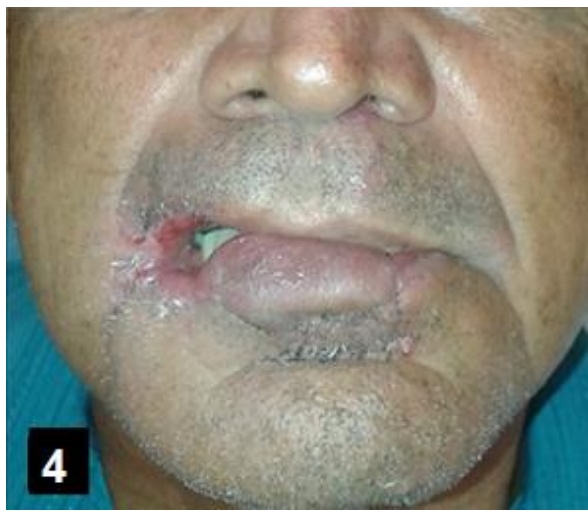

Figure 4: Postoperative aspect after 120 days.

\section{DISCUSSION}

The treatment of lip injuries requires delicate and planned manipulation to minimize possible sequela $^{3}$. In some cases, the loss of substance offer greater difficulty in reconstruction, requiring specialized techniques such as specific flaps or even grafts $^{7-9}$. Lip reconstructions can be performed by simple or dynamic techniques and the identification of anatomic references such: mucosal, cutaneous, muscular. The anatomical references during reconstruction is fundamental for quality in aesthetic and functional restoration ${ }^{1,2}$.

In this case report, the authors choose the primary closure technique. This technique had the objective of co-optation the edges of the wound, controlling the bleeding and repositioning the flap ${ }^{10}$. Small lip defects can be treated very well through a simple primary closure with excellent aesthetic results ${ }^{9}$. However, the direct closure can provide good functional and aesthetic results in extensive lip injuries ${ }^{1}$.

In large defects it is necessary to guide through the anatomical planes to avoid sequelae. ${ }^{1}$ In this cases, it is important to evaluate the extent of tissue loss because the correction of postoperative defects may be necessary through secondary surgery ${ }^{2}$. In this specific case, the primary anatomical closure technique was effective for immediate structural and allowed a favorable healing for the second surgical stage and the patient did not want to perform a new surgical procedure.

Defects involving the commissure require careful planning and, in some cases, late reconstruction will be necessary ${ }^{11}$. Many techniques are described in the literature for reconstruction of these defects and offer good results, restoring function and aesthetics ${ }^{12-14}$.

\section{CONCLUSION}

Although the correction of postoperative defects is necessary through secondary surgery, in this specific case, the primary anatomical closure technique was effective for immediate structural maintenance and allowed a favorable healing for the second surgical stage.

\section{REFERENCES}

1. Matin MB, Dillon J. Lip reconstruction. Oral Maxillofac Surg Clin North Am. 2014;26(3):335-57.

2. Lubek JE, Ord RA. Lip reconstruction. Oral Maxillofac Surg Clin North Am. 2013;25(2):103-14.

3. Cakmak MA, Cinal H, Barin EZ, Sakat MS, Karaduman H, Tan O. Total lower lip. reconstruction with functional gracilis free muscle flap. J Craniofac Surg. 2018;29(3):735-37.

4. Larrabee YC, Moyer JS. Reconstruction of mohs defects of the lips and chin. Facial Plast Surg Clin North Am. 2017;25(3):427-42.

5. Coppit GL, Lin DT, Burkey BB. Current concepts in lip reconstruction. Curr Opin Otolaryngol Head Neck Surg. 2004;12(4):281-87.

6. Daraei P, Calligas JP, Katz E, Etra JW, Sethna $\mathrm{AB}$. Reconstruction of upper lip avulsion after dog bite: case report and review of literature. Am J Otolaryngol. 2014;35(2):219-25.

7. Sanniec KJ, Carboy JA, Thornton JF. Simplifying Lip Reconstruction: An Algorithmic Approach. In Semin Plast Surg. 2018;32(2):69-74.

8. Neligan PC. Strategies in lip reconstruction. Clin Plast Surg. 2009;36(3):477-85.

9. Bai S, Li RW, Xu ZF, Duan WY, Liu FY, Sun CF. Total and near-total lower lip reconstruction: 20 years experience. J Craniomaxillofac Surg. 2015;43(3):367-72.

10. Ogawa R. Surgery for scar revision and reduction: from primary closure to flap surgery. Burns Trauma. 2019;7:7 doi: 10.1186/s41038-019-0144-5.

11. Siqueira EJ, Alvarez GS, Laitano FF, Martins PDE, Oliveira MP. Estratégias em reconstrução 
do lábio inferior. Rev Bras Cir Plást.2012;27(4):536-41.

12. Estlander JA. Eine methode aus der einen lippe substanzverluste der anderen zu erstzen. Arch Klin Chir. 1872;14:622. Reprinted in English in Plast Reconstr Surg. 1968;42:361.

13. Robotti E, Righi B, Carminati M, Ortelli L, Bonfirraro PP, Devalle L et al. Oral commissure reconstruction with orbicularis oris elastic musculomucosal flaps. J Plast Reconstr Aesthet Surg. 2010;63(3):431-39.

14. Yamauchi M, Yotsuyanagi T, Ezoe K, Saito T, Yokoi K, Urushidate S. Estlander flap combined with an extended upper lip flap technique for large defects of lower lip with oral commissure. J Plast Reconstr Aesthet Surg. 2009;62(8):997-1003.

\section{CONFLICTS OF INTERESTS}

The authors declare no conflicts of interests.

\section{CORRESPONDING AUTHOR}

\section{Laís Kawamata de Jesus}

kawamata_lais@hotmail.com 